\title{
Seminiferous propagation in the selection of chestnut tree rootstocks
}

\author{
Rafael Pio $^{1 *}$ Evaldo Tadeu de Melo ${ }^{1}$ João Pedro Sales Bueno ${ }^{1}$ \\ Luiz Fernando de Oliveira da Silva ${ }^{2}$ Pedro Maranha Peche ${ }^{1}$ Paula Nogueira Curi $^{1}$
}

${ }^{1}$ Universidade Federal de Lavras (UFLA), 37200-000, Lavras, MG, Brasil. E-mail: rafaelpio@dag.ufla.br. "Corresponding author. ${ }^{2}$ Empresa de Pesquisa Agropecuária de Minas Gerais (EPAMIG), Maria da Fé, MG, Brasil.

\begin{abstract}
Aiming the selection of rootstocks to produce seedlings, the objective of this study was to quantify the seminiferous propagation in chestnut seeds, with or without incisions. Nine cultivars were used ('Ibuki', 'Isumo', 'Kinshu', 'Moriwase', 'Okuni', 'Senri', 'Taishowase', 'Tamatsukuri' and 'Tiodowase') and two selections ('KM-1' and 'KM-2') of hybrid chestnut trees (Castanea crenata x Castanea sp.). An incision was held in half of chestnuts and the other half remained intact. Percentage of germination, emergence and root length were quantified. The germinated nuts were transplanted and were quantified the diameter and height of seedlings. Then, the chestnut selections 'KM-2' and 'Jacutinga' were grafted by the cleft grafting method, and were quantified the percentage of sprouting, besides the diameter and height of grafts. Incisions increase the germination and seedling emergence in most cultivars and selections. 'Taishowase' and 'Tamatsukuri'stood out over the others to germination, growth of the rootstocks.

Key words: Castanea crenata $x$ Castanea sp., incision, germination.
\end{abstract}

Propagação seminífera visando a seleção de porta-enxertos para castanheira

\begin{abstract}
RESUMO: Visando a seleção de porta-enxertos para a produção de mudas, o objetivo do trabalho foi quantificar a propagação seminifera em castanhas com ou sem a realização de incisões. Foram utilizadas nove cultivares ('Ibuki', 'Isumo', 'Kinshu', 'Moriwase', 'Okuni', 'Senri', 'Taishowase', 'Tamatsukuri'e 'Tiodowase') e duas seleções ('KM-1'e 'KM-2') de castanheira híbridas (Castanea crenata x Castanea sp.). Em metade das castanhas, realizou-se uma incisão e a outra metade das castanhas permaneceu intacta. Foram quantificadas a porcentagem de germinação, emergência e o comprimento das raizes. As castanhas germinadas foram transplantadas onde se quantificou o diâmetro e a altura das mudas e ao final, a massa seca da parte aérea. Em seguida foram enxertadas pelo método de garfagem as seleções de castanheira 'KM-2' e 'Jacutinga', se quantificando a porcentagem de brotação, além do diâmetro e altura dos enxertos. Concluiu-se que as incisões aumentam a germinação e a emergência das plântulas, na maioria das cultivares e seleções. 'Taishowase' e 'Tamatsukuri' se destacam em relação as demais quanto a germinação e crescimento dos porta-enxertos.

Palavras-chave: Castanea crenata $x$ Castanea sp., incisão, germinação.
\end{abstract}

The chestnut tree belongs to the Fagaceae family, Castanea genus. The Castanea genus comprises seven species of which the following are highlighted: C. sativa Miller, C. crenata Siebold \& Zucc., C. molissima Blume e C. dentata (Marsh.) Borkh. (BUENO \& PIO, 2014). In Brazil, imports of chestnut come basically from Portugal (98.5\%), with only $1.5 \%$ being Spain, among these some cultivars stand out 'Ibuki', 'Isumo', 'Kinshu', 'Moriwase', 'Okuni', 'Senri', 'Taishowase', 'Tamatsukuri' and 'Tiodowase' of Minas Gerais presenting high quality, but they are distinguished by their outstanding characteristics such as their chestnut and hedgehog dimensions, shape and chemical composition of each. But in addition the productive potential of each cultivar is still unknown. Some selections such as 'Km1' and 'KM2' were selected in São Bento do Sapucaí (BUENO \& PIO, 2014).

Chestnut cultivation may be encouraged because it is a viable alternative for agricultural diversification. However, due to cross-pollination, the preceding seed plants are unequifled in size, vigor and production of chestnut and their shape, which is unacceptable in a commercial production, due to this factor in Brazil, chestnuts are commercially produced by means of grafting (BUENO \& PIO, 2014).

Incision is a technique that consists of causing a trauma in the outermost seed tissues in order to break a possible mechanical barrier to expand the embryo and facilitate water intake. In addition to being 
simple and of low cost, this technique is effective in promoting fast and uniform seed germination (HERMANSEN, 2000). Nevertheless, it needs to be carefully used to prevent damages to vital seed tissues and reduction in germination. Cleft grafting is the most indicated technique for the production of chestnut tree seedlings. Thus, it is necessary to verify the growth of promising chestnut cultivars in Brazil that are grafted on available cultivars.

The objective of the present study was to quantify seminiferous propagation of chestnut trees, with and without the performance of incisions, in the selection of rootstocks for the production of chestnut grafted seedlings.

A total of 360 mature capsules were randomly harvested in mid-December 2013, in the morning, of plants of nine cultivars ('Ibuki', 'Isumo', 'Kinshu', 'Moriwase', 'Okuni', 'Senri', 'Taishowase', 'Tamatsukuri' and 'Tiodowase')) and two selections ('KM-1' and 'KM-2') of hybrid chestnuts (Castanea crenata $\mathrm{x}$ Castanea sp.), in the Center of Seedlings Production of Coordenadoria de Assistência Técnica Integral - CATI, of São Bento do Sapucaí, in the state of São Paulo. Chestnuts were removed from the capsules and 720 healthy chestnuts and without necrosis or cracks were selected. With the assistance of a pocketknife, an incision was performed on half of these chestnuts and the pericarp was removed from the thinnest layer; the other half remained intact. Chestnuts were planted $1 \mathrm{~cm}$ deep, in a bed of fine sand, located under a nursery covered with shading fabric at $50 \%$ brightness. The bed of sand was disinfected before use with sodium hypochlorite at $20 \%$. In this procedure, a liter of $2 \%$ sodium hypochlorite of the commercial brand Q-boa ${ }^{\circledR}$ was diluted in five liters of water and this solution was spread over the bed of sand with the assistance of a watering can.

A complete randomized experimental design was used, arranged in a 11 2 factorial scheme, being that the first factor was the chestnuts' selection and cultivars and the second factor was the performance of incision or its absence on the chestnuts, with four replications and 90 chestnuts per plot. After 40 days of sowing, the chestnuts were removed from the rooting bed in order to quantify the following: germination percentage, with germination being defined by the presence of radicle protrusion; emergence percentage, with emergence being defined as the presence of sprout emissions; and taproot mean length, which was measured with the assistance of a digital pachymeter.

Chestnuts that were geminated were transplanted into plastic bags that were placed in the same shaded nursery. In this phase, only 36 germinated chestnuts were used per plot. After the transplant, two variables were evaluated: stem height was quantified by measuring from the substrate to the apical edge using a tape measure with a precision of $1 \mathrm{~mm}$, and stem diameter was quantified at a height of $10 \mathrm{~cm}$ from the substrate, using a digital pachymeter. At the end of the second evaluation, conducted in October of 2014, the stems of 12 seedlings per plot were removed using pruning shears. Stem dry mass was obtained through drying vegetal matter in a greenhouse with a forced air circulation system at $65^{\circ} \mathrm{C}$ for 72 hours. Subsequently, it was weighed in a semi-analytical scale. Results obtained were subjected to a variance analysis, using the Scott-Knott test at 5\% probability.

In the evaluations pertaining the quantification in the germination bed, it was verified an interaction between the chestnuts' cultivars and selections and the incision conducted or its absence on the chestnuts. Regarding the values obtained in the germination percentage (Table 1) it was observed that when an incision was conducted on the chestnuts, significantly higher values were shown regardless of the cultivars used. Germination and emergence percentages of chestnut plantlets in which incision was not performed was relatively low, with the exception of 'KM-2' that registered $80 \%$ of germination (Table 1 ). In contrast, regarding the different cultivars and selections, the 'Isumo', 'Taishowase', 'Tamatsukuri', 'Tiodowase', and the selections 'KM-1' and 'KM-2' showed a higher germination rate, compared to the other cultivars, when the test was conducted with the performance of incision on the chestnuts; however, they were statistically similar to the germination of chestnuts that did not undergo an incision of the selection 'KM-2'. Performance of chestnut incision promoted a significant increase in the germination and emergence rates, especially in the 'Taishowase' $(32.5 \%$ and $42.5 \%$, respectively), 'Tamatsukuri' (30\% and 35\%, respectively), 'Tiodowase' ( $40 \%$ and $55 \%$, respectively), and in the selection 'KM2 ' (15\% and $22.5 \%$, respectively) (Table 1$)$. Incision in seeds promoted the contact of the embryo with the water and oxygen, generating an increase of germination and emergence of seeds, because the Portuguese chestnut has impermeable teguments.

Only 'Senri' and 'Kinshu' showed an increase of $12.5 \%$ of germination for both, and $10 \%$ and $12.5 \%$ in the emergence; respectively, in relation to chestnuts with and without incision. In addition, these cultivars showed the lowest germination and emergence rates (Table 1). Another explanation for the differences among cultivars in relation to the germination could be the chestnut dimensions and 
Table 1 - Plantlets germination percentage (\%) and emergence (\%) on the $60^{\text {th }}$ day after the sowing of 11 chestnut cultivars and selections, with or without incision on the chestnuts.

\begin{tabular}{|c|c|c|c|c|}
\hline \multirow{2}{*}{ Cultivar/Selection } & \multicolumn{2}{|c|}{--------'Germination $(\%)^{(1)}$} & \multicolumn{2}{|c|}{-------'Emergence $(\%)^{(1)}$} \\
\hline & Without incision & With incision & Without incision & With incision \\
\hline Ibuki & $30.0 \mathrm{Bc}$ & $65.0 \mathrm{Ab}$ & $17.5 \mathrm{Bc}$ & $60.0 \mathrm{Ac}$ \\
\hline Isumo & $32.0 \mathrm{Bc}$ & $87.5 \mathrm{Aa}$ & $22.5 \mathrm{Bc}$ & $80.0 \mathrm{Ab}$ \\
\hline KM-1 & $50.0 \mathrm{Bb}$ & $90.0 \mathrm{Aa}$ & $27.5 \mathrm{Bc}$ & $80.0 \mathrm{Ab}$ \\
\hline KM-2 & $80.0 \mathrm{Ba}$ & $95.0 \mathrm{Aa}$ & $70.0 \mathrm{Ba}$ & $92.5 \mathrm{Aa}$ \\
\hline Kinshu & $20.0 \mathrm{Ad}$ & $32.5 \mathrm{Ad}$ & $12.5 \mathrm{Ac}$ & $25.0 \mathrm{Ae}$ \\
\hline Moriwase & $20.0 \mathrm{Bd}$ & $50.0 \mathrm{Ac}$ & $12.5 \mathrm{Bc}$ & $42.5 \mathrm{Ad}$ \\
\hline Okuni & $45.0 \mathrm{Bb}$ & $80.0 \mathrm{Ab}$ & $40.0 \mathrm{Bb}$ & $75.0 \mathrm{Ab}$ \\
\hline Senri & $10.0 \mathrm{Ad}$ & $22.5 \mathrm{Ad}$ & $10.0 \mathrm{Ac}$ & $20.0 \mathrm{Ae}$ \\
\hline Taishowase & $57.5 \mathrm{Bb}$ & $90.0 \mathrm{Aa}$ & $45.0 \mathrm{Bb}$ & $87.5 \mathrm{Aa}$ \\
\hline Tamatsukuri & $65.0 \mathrm{Bb}$ & $95.0 \mathrm{Aa}$ & $60.0 \mathrm{Ba}$ & $95.0 \mathrm{Aa}$ \\
\hline Tiodowase & $60.0 \mathrm{Bb}$ & $100.0 \mathrm{Aa}$ & $45.0 \mathrm{Bb}$ & $100.0 \mathrm{Aa}$ \\
\hline $\mathrm{CV}(\%)$ & \multicolumn{2}{|c|}{19.5} & \multicolumn{2}{|c|}{19.8} \\
\hline
\end{tabular}

${ }^{(1)}$ Means followed by the same letter that was capitalized on the row and in small caps on the column do not differ from each other through the Scott-Knott $(\mathrm{P} \leq 0.05)$ test for grouping means.

mass; those chestnuts with greater mass present higher content of supplies. The main reserve substances in the seeds are carbohydrates, proteins and lipids. Proportion of this composition can vary from species to species and even among species of the same family. These substances are mobilized during germination and during the development of the seedlings their degradation products are used for different purposes, such as generation of energy and the production of raw material for the construction of new cells and tissues. Results are in agreement with DRESCH et al. (2013), which worked with Campomanesia adamantium, in which fruits of medium and small size had a higher percentage of germination, while fruits classified as large presented higher accumulation of biomass.

According to table 1, there was an $80 \%$ increase in emergence in chestnut cultivars, with 'Kinshu' and 'Senri' showing the least emergency, on the other hand 'KM2', 'Taishowase', 'Tamatsukuri' and Tiodowase 'presented the highest rates of emergence, being these recommended to obtain chestnut rootstock.

In the other evaluations, there was no interaction between the chestnuts' cultivars and selections and the incision on the chestnuts (Table 2). The 'Taishowase', 'Tamatsukuri', 'Tiodowase' and the selection 'KM-1' presented the greatest root lengths. Only 'Senri' did not develop well since the seedlings of this cultivar showed lower diameter, height, and dry matter of the aerial part (Table 2). In contrast, the seedlings of 'Kinshu', 'Ibuki', 'Okuni', 'Taishowase', 'Tamatsukuri,' and 'Tiodowase' presented the greatest heights and dry matter. Performance of incision on the chestnuts was effective in all evaluations conducted, not only for the length of the roots but also for the diameter, height, and dry matter of the aerial part (Table 2). Chestnut incisions doubled the roots' length and promoted an increase of $13 \mathrm{~cm}$ in the seedlings height, at the end of the $240^{\text {th }}$ day after transplant. It is possible that chestnuts that underwent incision initiated germination and emergence in advance compared to those chestnuts that did not undergo incision. This phenomenon could have accelerated the roots growth and the plants growth.

Regarding the development of grafts, there was no interaction between the chestnut cultivars and selections and the two selections grafted. There was no statistical difference in the sprouting percentage of grafts; however, it is noted that the rates were increased for the cultivars and selections as well as for the two selections grafted (Table 3). Regarding the development of grafts, when the cultivars 'Ibuki', 'Okuni', 'Taishowase,' and 'Tamatsukuri,' were used as rootstocks, they were associated with the greatest graft diameter and height. According to COMIOTTO et al. (2012), stronger rootstocks present greater capacity of absorption and translocation of water and nutrients, and greater production of growth-promoting substances, which benefits the development of the crown. 
Table 2 - Root length (RL, cm) on the $60^{\text {th }}$ day after the sowing, diameter $(\mathrm{D}, \mathrm{cm})$ and height $(\mathrm{H}$, cm) of seedlings 240 days after the transplant, and dry matter of the seedlings aerial part (DM, g) on the $240^{\text {th }}$ day after the transplant of the seedlings of 11 chestnuts' cultivars and selections, with or without the performance of incision on the chestnuts.

\begin{tabular}{|c|c|c|c|c|}
\hline Cultivar/Selection & $\mathrm{RL}(\mathrm{cm})^{(1)}$ & $\mathrm{D}(\mathrm{cm})^{(1)}$ & $\mathrm{H}(\mathrm{cm})^{(1)}$ & $\operatorname{DM}(g)^{(1)}$ \\
\hline \multicolumn{5}{|c|}{-----------------------------240 days------------------------- } \\
\hline Ibuki & $3.8 \mathrm{c}$ & $0.7 \mathrm{a}$ & $92.5 \mathrm{a}$ & $12.1 \mathrm{a}$ \\
\hline Isumo & $4.1 \mathrm{c}$ & $0.7 \mathrm{a}$ & $82.3 \mathrm{~b}$ & $10.7 \mathrm{a}$ \\
\hline KM-1 & $6.5 \mathrm{a}$ & $0.7 \mathrm{a}$ & $79.3 \mathrm{~b}$ & $11.5 \mathrm{a}$ \\
\hline KM-2 & $5.4 \mathrm{~b}$ & $0.7 \mathrm{a}$ & $82.6 \mathrm{~b}$ & $11.0 \mathrm{a}$ \\
\hline Kinshu & $3.1 \mathrm{c}$ & $0.7 \mathrm{a}$ & $86.4 \mathrm{a}$ & $10.8 \mathrm{a}$ \\
\hline Moriwase & $3.5 \mathrm{c}$ & $0.6 \mathrm{a}$ & $76.6 \mathrm{~b}$ & $10.0 \mathrm{~b}$ \\
\hline Okuni & $5.1 \mathrm{~b}$ & $0.7 \mathrm{a}$ & $90.4 \mathrm{a}$ & $11.1 \mathrm{a}$ \\
\hline Senri & $2.0 \mathrm{~d}$ & $0.3 \mathrm{~b}$ & $35.7 \mathrm{c}$ & $6.46 \mathrm{c}$ \\
\hline Taishowase & $6.2 \mathrm{a}$ & $0.7 \mathrm{a}$ & $97.5 \mathrm{a}$ & $12.4 \mathrm{a}$ \\
\hline Tamatsukuri & $6.8 \mathrm{a}$ & $0.7 \mathrm{a}$ & $85.3 \mathrm{a}$ & $10.8 \mathrm{a}$ \\
\hline Tiodowase & $6.9 \mathrm{a}$ & $0.6 \mathrm{a}$ & $90.0 \mathrm{a}$ & $11.9 \mathrm{a}$ \\
\hline \multicolumn{5}{|l|}{ Incision } \\
\hline With & $3.1 \mathrm{~b}$ & $0.5 \mathrm{~b}$ & $73.4 \mathrm{~b}$ & $10.0 \mathrm{~b}$ \\
\hline Without & $6.3 \mathrm{a}$ & $0.7 \mathrm{a}$ & $86.4 \mathrm{a}$ & $11.8 \mathrm{a}$ \\
\hline CV (\%) & 27.7 & 9.4 & 7.8 & 17.3 \\
\hline
\end{tabular}

${ }^{(1)}$ Means followed by the same letter do not differ from each other through the Scott-Knott $(\mathrm{P} \leq 0.05)$ test for grouping means.

Incisions on chestnuts increase plantlets germination and emergence rates in most cultivars and selections. 'Taishowase' and 'Tamatsukuri' excel over the other cultivars in relation to germination and rootstocks growth and of cultivars that are grafted on them.

Table 3 - Sprouting percentage $(\%)$ on the $60^{\text {th }}$ day after the grafting, diameter $(\mathrm{cm})$ and height $(\mathrm{cm})$ of the grafts on the $120^{\text {th }}$ day after the grafting of two chestnut selections that were grafted in 11 cultivars and selections of chestnuts.

\begin{tabular}{lccc}
\hline Cultivar/Selection & Sprouting $(\%)^{(1)}$ & Diameter $(\mathrm{cm})^{(1)}$ & Height $(\mathrm{cm})^{(1)}$ \\
\hline Ibuki & 87.5 & $5.0 \mathrm{a}$ & $31.4 \mathrm{a}$ \\
Isumo & 80.0 & $4.0 \mathrm{~b}$ & $25.7 \mathrm{~b}$ \\
KM-1 & 94.5 & $3.5 \mathrm{~b}$ & $20.6 \mathrm{c}$ \\
KM-2 & 80.5 & $3.2 \mathrm{~b}$ & $22.0 \mathrm{c}$ \\
Kinshu & 86.5 & $3.6 \mathrm{~b}$ & $19.5 \mathrm{c}$ \\
Moriwase & 83.5 & $3.9 \mathrm{~b}$ & $31.1 \mathrm{a}$ \\
Okuni & 83.5 & $5.9 \mathrm{a}$ & $28.0 \mathrm{a}$ \\
Senri & $89.0^{\mathrm{ns}}$ & $3.4 \mathrm{~b}$ & $8.6 \mathrm{~d}$ \\
Taishowase & 81.5 & $4.8 \mathrm{a}$ & $29.3 \mathrm{a}$ \\
Tamatsukuri & 81.5 & $4.8 \mathrm{a}$ & $29.6 \mathrm{a}$ \\
Tiodowase & 88.0 & $3.7 \mathrm{~b}$ & $19.0 \mathrm{c}$ \\
Grafted Selection & & & $20.2 \mathrm{~b}$ \\
Jacutinga & 83.3 & $4.2 \mathrm{a}$ & $25.8 \mathrm{a}$ \\
KM-2 & $84.9^{\mathrm{ns}}$ & $3.6 \mathrm{~b}$ & 22.6 \\
CV $(\%)$ & 19.6 & 18.6 & \\
\hline
\end{tabular}

${ }^{(1)}$ Means followed by the same letter do not differ from each other by the Scott-Knott $(\mathrm{P} \leq 0.05)$ test for grouping means. ns - nonsignificant. 


\section{REFERENCES}

BUENO, S.C.S.; PIO, R. Castanha tipo portuguesa no Brasil. Revista Brasileira de Fruticultura, v.36, p.16-22, 2014. Available from: <http://www.scielo.br/scielo.php?script=sci_ar ttext\&pid $=$ S0100-29452014000100004>. Accessed: Nov. 01, 2016. doi: 10.1590/0100-2945-442/13.

COMIOTTO,A. et al. Vigor, floração, produção e qualidade de pêssegos 'Chimarrita'e 'Maciel' em função de diferentes porta-enxertos. Ciência Rural, v.42, p.788-794, 2012. Available from: <http://www.scielo. br/scielo.php?script=sci arttext\&pid $=$ S0103-84782012000500005 $>$. Accessed: Nov. 02, 2016. doi: 10.1590/S0103-84782012000500005.

DRESCH, D.M. et al. Germinação e vigor de sementes de gabiroba em função do tamanho do fruto e semente. Pesquisa Agropecuária
Tropical, v.43, p.262-271, 2013. Available from: <http://www.scielo. br/pdf/pat/v43n3/a06.pdf $>$. Accessed: Apr. 28, 2017. doi: 10.1590/ S1983-40632013000300006.

HERMANSEN, L.A. Pretreatments to overcome seed coat dormancy in Dimorphandra mollis. Seed Science \& Technology, v.28, p.581-595, 2000. Available from: <https:// www.researchgate.net/publication/292009774_Pretreatments to_overcome_seed_coac_dormancy_in_Dimorphandra_mollis $>$. Accessed: Nov. 08, 2016.

PIO, R. et al. Época de maturação, caracterização física e química de cultivares e seleções de castanheiro. Revista Brasileira de Fruticultura, v.36, p.525-531, 2014. Available from: <http://www.scielo.br/scielo. php?script $=$ sci_arttext\&pid $=$ S0100-29452014000300003 $>$. Accessed: Nov. 06, 2016. doi: 10.1590/0100-2945-254/13. 